\title{
The effects of serine proteinase inhibitors on bone resorption in vitro
}

\author{
A Tumber, S Papaioannou, J Breckon, M C Meikle, J J Reynolds \\ and $\mathbf{P}$ A Hill
}

Department of Orthodontics and Paediatric Dentistry, United Medical and Dental Schools of Guy's, King's and St Thomas' Hospitals, University of London, London SE1 9RT, UK

(Requests for offprints should be addressed to P A Hill; peter.hill@kcl.ac.uk)

\begin{abstract}
The aims of this study were to identify the role and sites of action of serine proteinases (SPs) in bone resorption, a process which involves a cascade of events, the central step of which is the removal of bone matrix by osteoclasts (OCs). This resorbing activity, however, is also determined by recruitment of new OCs to future resorption sites and removal of the osteoid layer by osteoblasts (OBs), which enables OCs to gain access to the underlying mineralized bone. The resorption systems we have studied consisted of (i) neonatal calvarial explants, (ii) isolated OCs cultured on ivory slices, (iii) mouse OBs cultured on either radiolabelled type I collagen films or bone-like matrix, (iv) bone marrow cultures to assess OC formation and (v) 17-day-old fetal mouse metatarsal bone rudiments to assess OC migration and fusion.

Two separate SP inhibitors, aprotinin and $\alpha_{2^{-}}$ antiplasmin dose-dependently inhibited ${ }^{45} \mathrm{Ca}$ release from neonatal calvarial explants: aprotinin $\left(10^{-6} \mathrm{M}\right)$ was the most effective SP inhibitor, producing a maximum inhibitory effect of $55 \cdot 9 \%$.
\end{abstract}

Neither of the SP inhibitors influenced either OC formation or OC resorptive activity. In contrast, each SP inhibitor dose-dependently inhibited OB-mediated degradation of both type I collagen fibrils and nonmineralized bone matrix. In 17-day-old metatarsal explants aprotinin produced a 55\% reduction in the migration of OCs from the periosteum to the mineralized matrix after 3 days in culture but after 6 days in culture aprotinin was without effect on OC migration. Primary mouse osteoblasts expressed mRNA for urokinase type plasminogen activator (uPA), tissue type plasminogen activator (tPA), the type I receptor for uPA, plasminogen activator inhibitor types I and II and the broad spectrum serine proteinase inhibitor, protease nexin I. In situ hybridization demonstrated expression of tPA and uPA in osteoclasts disaggregated from 6-day-old mouse long bones. We propose that the regulation of these various enzyme systems within bone tissue determines the sites where bone resorption will be initiated.

Journal of Endocrinology (2003) 178, 437-447

\section{Introduction}

Bone resorption involves the removal of both the mineral and organic constituents of bone matrix. Osteoclasts are the cells principally responsible for this process which occurs in the subosteoclastic resorption zone (SORZ), a specialized extracellular compartment bounded by the ruffled border of the cell and the mineralized bone matrix (Baron 1989). Osteoclasts acidify the SORZ leading to dissolution of mineral (Blair et al. 1989) while the organic matrix is believed to be degraded by lysosomal cysteine proteinases, matrix metalloproteinases (MMPs) and also serine proteinases (Hill et al. 1995). Bone resorption is also governed by the recruitment of new osteoclasts from progenitor cells of the mononuclear phagocyte system (Suda et al. 1992). The mononuclear precursors are disseminated via the bloodstream and deposited in the mesenchyme surrounding bone rudiments where they proliferate into preosteoclasts prior to migrating to future resorption sites (Blavier \& Delaisse, 1995). Osteoblasts play an accessory role in bone resorption by releasing proteinases that degrade the surface osteoid layer (principally type I collagen), facilitating the access of osteoclasts to mineralized bone (Chambers et al. 1985).

The plasminogen activators (PAs), urokinase type PA $(\mathrm{uPA})$ and tissue type PA (tPA), are serine proteinases that catalyse the conversion of the proenzyme plasminogen into a broad spectrum serine protease, plasmin. Plasmin can either directly or indirectly via activation of latent MMPs promote the degradation of all components of the extracellular matrix in vitro (Murphy et al. 1992, Mignatti \& Rifkin 1993). With regard to a possible involvement of serine proteinases in bone turnover, plasminogen has been shown to be present in extracellular matrices 
(Knudsen et al. 1986). Furthermore, osteoblasts produce PAs in response to agents that promote bone resorption (Fukumoto et al. 1992, Allan \& Martin 1995) and most recently it has been suggested that serine proteinases are involved in the degradation of non-collagenous proteins of bone (Daci et al. 1999). Although these results support the notion that the PA/plasmin system might be involved in bone resorption, results from other studies suggest a limited role (Leloup et al. 1994, 1996).

Since plasminogen is the most abundant and best defined substrate for PAs and its activation by PAs results in the generation of plasmin (Vassalli et al. 1991), the importance of plasmin activity to the normal sequence of events that leads to bone resorption was investigated in this study. We assessed the contribution of the PA/plasmin system to the different aspects of the bone resorption cascade using selective inhibitors of serine proteinases (SPs) in combination with a variety of in vitro models that are specific for the various aspects of the resorption process. Furthermore, an assessment was made of the expression of the SPs and their natural inhibitors in these model systems by RT-PCR and in situ hybridization.

\section{Materials and Methods}

\section{Materials}

Cell culture reagents and the SP inhibitors, aprotinin and $\alpha_{2}$-antiplasmin, were purchased from Sigma Chemical Co. (Poole, Dorset, UK). ${ }^{45} \mathrm{CaCl}_{2},{ }^{14} \mathrm{C}$ and ${ }^{3} \mathrm{H}-$ amino acid mixture were purchased from Amersham International (Aylesbury, Bucks, UK). Enzymes and reagents for RT-PCR were purchased as a kit from Applied Biosystems (Foster City, CA, USA). The MMP inhibitor, CT1399, and the cysteine proteinase inhibitor, Ep453, were gifts from Dr A Docherty (Celltech, UK) and Dr M Murata (Research Centre, Taisho Pharmaceuticals, Japan) respectively.

\section{Methods}

Preparation of acid-treated serum To destroy serum inhibitors of neutral proteinases, aliquots $(20 \mathrm{ml})$ of heatinactivated calf serum (Globepharm, Esher, Surrey, UK) were acidified to $\mathrm{pH} 3 \cdot 2$ with $1 \mathrm{M} \mathrm{HCl}$ and incubated for $35 \mathrm{~min}$ at $37^{\circ} \mathrm{C}$. The $\mathrm{pH}$ was then returned to $7 \cdot 4$ with $1 \mathrm{M} \mathrm{NaOH}$. This serum was used in all the assays.

Neonatal calvarial assay Bone resorption was assessed by analysing ${ }^{45} \mathrm{CaCl}_{2}$ release from prelabelled cultured neonatal mouse calvarial bones (Reynolds \& Dingle 1970). Briefly, 1-day-old mice were injected s.c. with $0 \cdot 1$ megabecquerels ${ }^{45} \mathrm{CaCl}_{2}$. Six days later calvarial bones were excised and cultured in pairs in CMRL 1066 medium ( $2 \mathrm{ml}$ ) containing 5\% acid-treated fetal calf serum (FCS) for up to 4 days with media changes every two days. Mobilization of radioactivity was expressed as the percentage release of initial isotope (calculated as the sum of radioactivity in medium and bone after culture). To determine ${ }^{45} \mathrm{Ca}^{2+}$ release due to passive exchange of isotope with cold $\mathrm{Ca}^{2+}$ in the culture medium, two bones from each litter were devitalized by three cycles of freeze-thawing. The percentage release from the devitalized bone was subtracted from each living bone to give the amount of cell-mediated resorption. The bones were stimulated with either parathyroid hormone $(\mathrm{PTH})$ $\left(10^{-8} \mathrm{M}\right)$ or 1,25 -dihydroxyvitamin $\mathrm{D}_{3}\left(1,25-(\mathrm{OH})_{2} \mathrm{D}_{3}\right)$ $\left(10^{-8} \mathrm{M}\right)$.

Isolated osteoclast assay The osteoclast bone resorption assay is based on the ability of isolated osteoclasts to resorb devitalized cortical bone, dentine, or ivory slices in vitro (Boyde et al. 1984). Ivory slices $(200 \mu \mathrm{m})$ were cut with a low speed water-cooled diamond saw (Isomet, Buehler, Coventry, UK) from a $1-\mathrm{cm}^{2}$ rod. Ivory slices were chosen because they are free of vascular systems and pre-existing resorbing surfaces; osteoclasts can resorb ivory. Osteoclasts were prepared from femurs of 2- to 3-day-old mice. Osteoclasts were allowed to settle for $20 \mathrm{~min}$ at $37^{\circ} \mathrm{C}$. The substrate was then washed free of nonadherent cells, and the slices were incubated for $24 \mathrm{~h}$ in a humidified atmosphere of $5 \% \mathrm{CO}_{2}-95 \%$ air at $37{ }^{\circ} \mathrm{C}$ in $500 \mu \mathrm{l} \alpha$-MEM supplemented with acid-treated 5\% FCS, 2.0 g/1 $\mathrm{NaHCO}_{3}, 2 \mathrm{mM}$ L-glutamine, $100 \mathrm{U} / \mathrm{ml}$ penicillin and $100 \mu \mathrm{g} / \mathrm{ml}$ streptomycin. Due to the variability in the number of osteoclasts isolated from each mouse, a single experiment consisted of 6 ivory slices bearing the cells from one mouse, with 3 slices for each control and test variable. Each experimental variable was repeated 4 times, and the results were expressed as the treated-to-control ratio.

At the completion of the culture period, the cells were removed from the ivory slices. The method used for the precise quantitation of the resorptive capacity involved estimating the surface area of the resorption lacunae by image analysis (TC Image, Foster Finlay Associates, UK).

Murine bone marrow cultures A mouse bone marrow culture system was used to assess osteoclast differentiation (Takahashi et al. 1988). In brief, tibiae were removed from 5 -week-old mice and marrow cells were plated in 24-well dishes and incubated in the presence of $1,25-(\mathrm{OH})_{2} \mathrm{D}_{3}$. The latter agent has been shown to stimulate the formation of tartrate-resistant acid phosphatase (TRAP)-positive (TRAP+ve) osteoclast-like multinucleate cells (MNCs). After 8 days, the cultures were stained for TRAP and the cells counted.

Metatarsal long bone assay The three middle metatarsals of each hindlimb of 17-day-old mouse embryos (day of vaginal plug discovery equals day 0 of gestation) were 
dissected as a triad (Blavier \& Delaisse 1995). One triad of each pair was cultured as a control, the other as a test. Each triad was cultured in $1 \mathrm{ml}$ CMRL 1066 medium supplemented with glutamine $(200 \mathrm{mg} / \mathrm{l}), 10 \%$ acid-treated FCS with $1,25-(\mathrm{OH})_{2} \mathrm{D}_{3}\left(10^{-8} \mathrm{M}\right)$. The cultures were run for 3 and 6 days and were then fixed in $4 \%$ paraformaldehyde overnight at $4{ }^{\circ} \mathrm{C}$. Specimens were then washed in PBS, decalcified in 5\% EDTA overnight, dehydrated through a graded series of ethanol and embedded in paraffin. Sections of $5 \mu \mathrm{m}$ were cut and transferred to sialinized glass slides (Sigma). Sections were stained for TRAP and counterstained with haematoxylin.

Histomorphometry The number of TRAP-positive cells and their nuclei were determined in 10 evenly spaced longitudinal sections per long bone rudiment. According to their location they were scored as (1) lying in the developing marrow cavity, that is the area of resorbing calcified cartilage surrounded by the thin bone collar or (2) in the periosteum-perichondrium, that is the soft tissue around the bone rudiment. The few cells lying within the (thin) bone collar were equally divided over the two compartments.

Preparation of osteoblasts from neonatal mouse calvariae Calvarial osteoblasts were prepared and characterized as previously described (Heath et al. 1984).

\section{Preparation of collagen films}

Radiolabelled collagen films were prepared as described previously (Gavrilovic et al. 1985).

Culture of osteoblasts on collagen films Osteoblasts $\left(1 \times 10^{5} /\right.$ well $)$ were settled onto collagen films in $1 \mathrm{ml}$ DMEM plus $10 \%$ acid-treated FCS, incubated for $16 \mathrm{~h}$ at $37^{\circ} \mathrm{C}$ and washed with serum-free DMEM. Cells were then cultured in DMEM (1 ml) supplemented with 5\% acid-treated serum as described above. Then 1,25$(\mathrm{OH})_{2} \mathrm{D}_{3}\left(10^{-8} \mathrm{M}\right)$ (added in $5 \mu$ ethanol) alone or $1,25-(\mathrm{OH})_{2} \mathrm{D}_{3}$ plus either aprotinin or CT1399, or ethanol alone was added to the wells and the cultures were maintained at $37{ }^{\circ} \mathrm{C}$ for $48 \mathrm{~h}$. The basal release of ${ }^{14} \mathrm{C}$ by unstimulated osteoblasts was subtracted from the 1,25$(\mathrm{OH})_{2} \mathrm{D}_{3}$-stimulated release in the presence and absence of inhibitors to give the corrected values for stimulated lysis. At the end of the culture period, the media were centrifuged $(15 \mathrm{~min}, 1200 \mathrm{~g})$ to remove any collagen fibrils, and radioactivity released during collagen degradation was quantified by liquid scintillation counting. Residual collagen was digested with bacterial collagenase $(50 \mu \mathrm{g} / \mathrm{ml})$ and assayed for radioactivity. Collagenolysis was expressed as radioactivity released from the films as a percentage of the total \pm S.E.M.

Formation of ${ }^{3} \mathrm{H}$-labelled extracellular bone matrix The murine calvaria-derived cell line, MC3T3-E1, is a well characterized osteoblast culture system providing a suitable model of osteogenesis analogous to in vivo bone formation (Quarles et al. 1992). In the present study, an extracellular bone-like matrix was produced as described by Ronday et al. (1997). MC3T3-E1 cells were plated at a density of $1 \times 10^{4}$ cells/well on collagen-coated 24-well plates (Becton Dickinson, Bedford, MA, USA) and cultured in MEM supplemented with $10 \%$ FBS, $50 \mu \mathrm{g} / \mathrm{ml}$ ascorbic acid. After 4-5 days, when the cultures had reached confluence and the formation of an extracellular matrix had started, fresh medium was added containing $1 \mu \mathrm{Ci} / \mathrm{ml}{ }^{3} \mathrm{H}$-amino acid mixture (Amersham International) to create a non-mineralized radiolabelled extracellular bone matrix. After 14 days, cells were lysed with $0.5 \mathrm{ml} /$ well Triton X-100 (0.5\% v/v in PBS). The cytoskeleton was removed by $25 \mathrm{mM} \mathrm{NH}_{4} \mathrm{OH}$ treatment and $1 \mathrm{mM}$ phenylmethylsulphonyl fluoride $(0.5 \mathrm{ml} /$ well $)$ treatment was used to block proteinase activity. Matrices were washed with $\mathrm{H}_{2} \mathrm{O}$ and $75 \%(\mathrm{v} / \mathrm{v})$ ethanol to remove unincorporated ${ }^{3} \mathrm{H}$-radiolabelled amino acids, dried and stored at $-20{ }^{\circ} \mathrm{C}$.

Bone matrix degradation assay To assay for matrix degradation, osteoblasts were plated onto the matrices as for the collagen film assays. After $72-\mathrm{h}$ incubation, the media were removed and the extent of degraded ${ }^{3} \mathrm{H}-$ radiolabelled matrix released into the medium was determined by liquid scintillation counting. The remaining matrix was degraded with $0 \cdot 25 \%(\mathrm{w} / \mathrm{v})$ trypsin, $0 \cdot 1 \%$ $(\mathrm{w} / \mathrm{v})$ collagenase in PBS for $1 \mathrm{~h}$ at $37^{\circ} \mathrm{C}$, and the amount of radioactivity in the matrix similarly assessed. Matrix degradation was expressed as ${ }^{3} \mathrm{H}$ released in the medium as a percentage of the total amount of ${ }^{3} \mathrm{H}$ released by the cells during the 72-h culture period, plus that solubilized from the remaining matrix by trypsin/collagenase treatment.

Reverse transcriptase-polymerase chain reaction (RT-PCR) RNA was extracted using an RNA isolation kit (Stratagene, Amsterdam, The Netherlands). RT-PCR reactions were performed using the GeneAmp rTth Reverse Transcriptase RNA PCR Kit (Applied Biosystems, St. Louis, MO, USA) and a Stratagene Robocycler Gradient 96 PCR machine (Stratagene). Synthetic oligonucleotide sequences specific for tPA, uPA, uPA receptor (uPAR), plasminogen activator inhibitor types I and II (PAI-1 and PAI-2) and protease nexin 1 (PN-1) were synthesized by Life Technologies Ltd (Paisley, Strathclyde, UK) using previously published sequence data (Yang et al. 1997) and are shown in Table 1.

Band size was checked against molecular weight standards (X174 HaeIII digest) and sequenced to confirm authenticity.

Preparation of $\mathbf{u P A}$ and tPA riboprobes The expected DNA fragment for tPA was excised and purified from a TAE gel using a QIAquick Gel Extraction Kit (Qiagen). 
Table 1 Oligonucleotide RT-PCR primer sequences for mouse PAs

\begin{tabular}{|c|c|c|}
\hline & Primer sequence & $\begin{array}{l}\text { Expected } \\
\text { product } \\
\text { length (bp) }\end{array}$ \\
\hline \multicolumn{3}{|l|}{ Gene } \\
\hline \multirow[t]{2}{*}{ tPA } & F5'-GACGATACTTATGACAACGAC-3' & 255 \\
\hline & R5'-TATTAAACAGATGCTGTGAGG-3' & \\
\hline \multirow[t]{2}{*}{ uPA } & F5'-CGAATACTACAGGGAAGAC-3' & 219 \\
\hline & R5'-GACATTTTCAGGTTCTTTGG-3' & \\
\hline \multirow[t]{2}{*}{ uPAR1 } & F5'-АTTGССТСТСТGСТССТGАС-3' & 331 \\
\hline & R5'-GAGACCCAАCСТTАТTCACTG-3' & \\
\hline \multirow[t]{2}{*}{ PAI-1 } & F5'-ATCCTGCСTAAGTTCTCTCTG-3' & 290 \\
\hline & R5'-ATTGTCTCTGTCGGGTTGTG-3' & \\
\hline \multirow[t]{2}{*}{ PAI-2 } & 'F5'-CAAAGCTGAACATTGGATAC-3' & 205 \\
\hline & R5'-ACCACAACATCATCTTCATC-3' & \\
\hline \multirow[t]{2}{*}{$\mathrm{PN}-1$} & F5'-GCGATATAATGTAAACGGAG-3' & 225 \\
\hline & R5'-CAAAAATTGATGGACTCAGAG-3' & \\
\hline \multirow[t]{2}{*}{ GAPDH } & F5'-CCACGAGAAATATGACAAC-3' & 222 \\
\hline & R5'-GATGCAGGGATGATGTTC-3' & \\
\hline
\end{tabular}

$F$, forward; R, reverse.

The fresh PCR product was ligated to pGEM-T vector (Promega) using T4 DNA ligase (Promega). The probe for uPA was a generous gift from Dr J D Vassalli (University of Geneva) and consisted of a 660 base pair fragment cloned into the PstI/HindIII site of plasmid pSP64. The plasmids were transformed to competent JM109 E. coli plasmid DNA extracted using a method based on Qiagen Maxiprep DNA purification (Qiagen). Plasmids were linearized with BamH1 for synthesis of digoxigenin-11UTP riboprobes. Plasmids were linearized with NcoI and SpeI for synthesis of digoxigenin-11-UTP-labelled riboprobes. The probe for MMP-9 was a generous gift from Dr K Tryggvason (Karolinska Institute, Sweden).

Statistical analysis Data are expressed as means \pm S.E.M. Differences between control and treatment groups were determined by the Mann-Whitney $U$ test. Significant differences from control are represented by $* P<0 \cdot 05$, $* * P<0 \cdot 01$ and $* * * P<0 \cdot 001$.

\section{Results}

\section{Calvarial bone resorption}

To determine the role of SPs in bone resorption, a neonatal calvarial assay was used. This assay simultaneously screens for activities influencing various aspects of the bone resorption process including osteoclast fusion and migration to resorption sites, osteoclast activity and osteoblast-mediated degradation of type I collagen. When the calvarial explants were cultured in normal FCS, the SP inhibitors did not prevent bone resorption (data not shown). However, when the calvarial explants were cultured in acid-treated FCS which is devoid of inhibitors

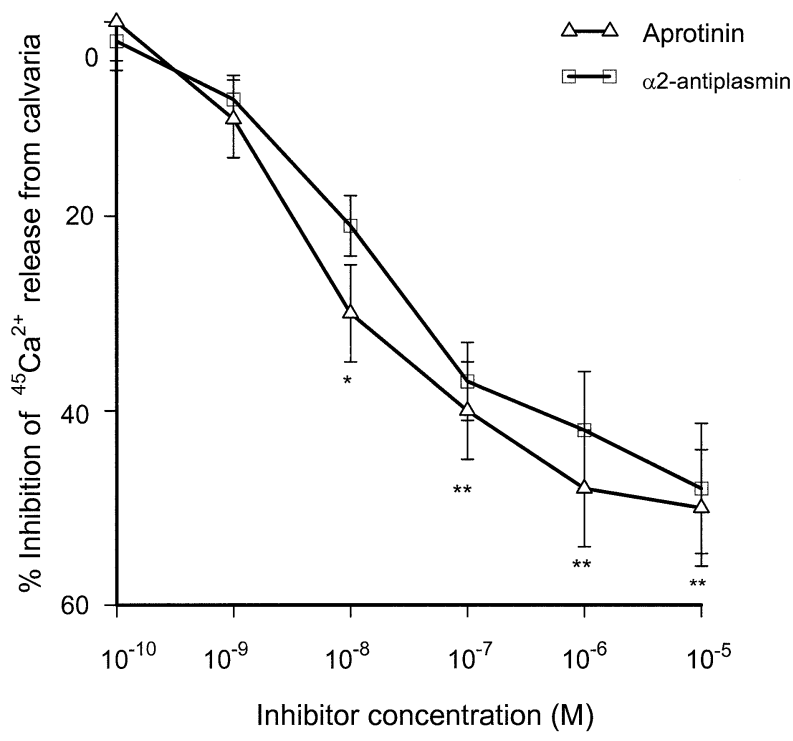

Figure 1 Effects of SP inhibitors on the PTH-stimulated release of ${ }^{45} \mathrm{Ca}^{2+}$ from calvarial bones after a 48 -h incubation period. The results are expressed as percentage inhibition of PTH-stimulated ${ }^{45} \mathrm{Ca}$ release which was arbitrarily set at $100 \%$. Each value is the mean \pm S.E.M. of 5 pairs of bones. The inhibitory effects of aprotinin $\left(10^{-8}-10^{-5} \mathrm{M}\right)$ and $\alpha_{2}$-antiplasmin $\left(10^{-8}-10^{-5} \mathrm{M}\right)$ were statistically significant $\left({ }^{*} P<0 \cdot 05,{ }^{* *} P<0 \cdot 01\right)$. The percentage release of ${ }^{45} \mathrm{Ca}$ from PTH-stimulated bones was $25 \cdot 6 \pm 4 \cdot 3$ for aprotinin and $23.6 \pm 3.6$ for $\alpha_{2}$-antiplasmin. Both inhibitors dose-dependently inhibited release of ${ }^{45} \mathrm{Ca}$.

of neutral proteinase activity each SP inhibitor dosedependently inhibited ${ }^{45} \mathrm{Ca}$ release, in the range $10^{-10}$ to $10^{-5} \mathrm{M}$ (Fig. 1). During the 4 days of culture, aprotinin and $\alpha_{2}$-antiplasmin produced a maximal inhibition of approximately $50 \%$ of ${ }^{45} \mathrm{Ca}$ release at a concentration of $10^{-5} \mathrm{M}$. To determine whether the inhibitory effect was reversible, a recovery experiment was carried out. Calvarial bones were treated with PTH $\left(10^{-9} \mathrm{M}\right)$ and either aprotinin $\left(10^{-5} \mathrm{M}\right)$ or $\alpha_{2}$-antiplasmin $\left(10^{-5} \mathrm{M}\right)$ for the first $48 \mathrm{~h}$ and then cultured in the presence of PTH for 48-96 h. The inhibitory effects of the compounds seen during the initial culture period were subsequently lost (Table 2). PTH-stimulated release of ${ }^{45} \mathrm{Ca}$ returned to levels observed without addition of inhibitors during the 0-48 h culture period.

\section{Osteoclast pit formation on ivory slices}

Figure 2 shows that aprotinin did not prevent osteoclast resorptive activity on ivory slices, producing only a $2 \%$ inhibition in pit number and a $5 \%$ inhibition in surface area resorbed. In contrast, a CP inhibitor, Ep453 $\left(10^{-5} \mathrm{M}\right)$, produced significant inhibition of osteoclast activity of approximately $80 \%$ for both number of pits and the surface area resorbed. Similarly, the MMP inhibitor, 
Table 2 Recovery from the inhibitory effects of aprotinin and $\alpha_{2}$-antiplasmin on the PTH-stimulated release of ${ }^{45} \mathrm{Ca}$ from mouse calvarial bones in culture. Values are means \pm S.E.M. for five calvarial bones prelabelled with $0.37 \mathrm{Mbq}{ }^{45} \mathrm{Ca}$

\section{Treatment $^{\dagger}$}

\begin{tabular}{|c|c|c|c|}
\hline $0-48 \mathrm{~h}$ & $49-96 \mathrm{~h}$ & $0-48 \mathrm{~h}$ & $49-96 \mathrm{~h}$ \\
\hline PTH & PTH & $17 \cdot 2 \pm 2 \cdot 1$ & $13 \cdot 3 \pm 2 \cdot 6$ \\
\hline PTH+aprotinin & PTH & $9 \cdot 1 \pm 1 \cdot 5^{*}$ & $15 \cdot 2 \pm 2 \cdot 1$ \\
\hline PTH $+\alpha_{2}$-antiplasmin & PTH & $8 \cdot 3 \pm 2 \cdot 3^{*}$ & $12 \cdot 6 \pm 1 \cdot 6$ \\
\hline
\end{tabular}

${ }^{\dagger} \mathrm{PTH}$, aprotinin and $\alpha_{2}$-antiplasmin were added at final concentrations of $10^{-9} \mathrm{M}, 10^{-5} \mathrm{M}$, and $10^{-5} \mathrm{M}$ respectively. ${ }^{*}$ Significantly different from PTH alone at $P<0 \cdot 05$.

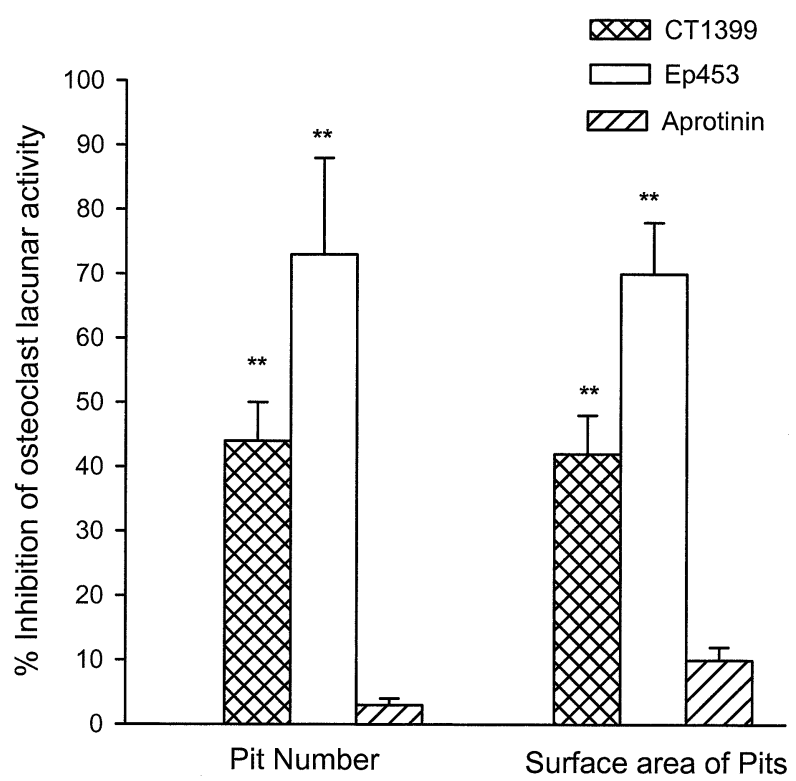

Figure 2 Effects of proteinase inhibitors on the number and the total surface area of mouse osteoclast lacunae. Each value is the percentage inhibition in interleukin (IL)- $1 \alpha$-stimulated osteoclast lacunar resorption arbitrarily set at $100 \%$. The values represent the means \pm S.E.M. from five individual experiments representing 15 slices for each variable. The number and surface area of pits on the Ep453- and CT1399-treated slices were significantly different from control $\left({ }^{*} P<0 \cdot 01\right)$. The number of lacunae in the control cultures was 1021 (Ep453), 1293 (CT1399) and 879 (aprotinin).

CT1399, produced a significant decrease in osteoclast activity of approximately $45 \%$ for pit number and surface area resorbed.

\section{Osteoclast formation in vitro}

Murine bone marrow cells stimulated with $1,25-(\mathrm{OH})_{2} \mathrm{D}_{3}$ were used to assess the effects of the SPs on osteoclast formation. Maximal numbers of osteoclasts, identified as TRAP+ve MNCs were formed by $1,25-(\mathrm{OH})_{2} \mathrm{D}_{3}$ at a concentration of $10^{-8} \mathrm{M}$. The addition of either aprotinin
Table 3 The effects of SP inhibitors on TRAP+ve MNC formation. Results are expressed as means \pm S.E.M. of 6 wells from

2 experiments

\section{Number of TRAP-positive MNCs per well}

\begin{tabular}{ll}
\cline { 2 - 2 } Treatment & \\
$1,25-(\mathrm{OH})_{2} \mathrm{D}_{3}$ & $65 \pm 12$ \\
$1,25-(\mathrm{OH})_{2} \mathrm{D}_{3}+\mathrm{C} 1399$ & $69 \pm 8$ \\
$1,25-(\mathrm{OH})_{2} \mathrm{D}_{3}+$ aprotinin & $73 \pm 13$ \\
$1,25-(\mathrm{OH})_{2} \mathrm{D}_{3}+\alpha_{2}$-antiplasmin & $62 \pm 10$
\end{tabular}

Mouse bone marrow cells were cultured as described in Materials and Methods in the presence of $1,25-(\mathrm{OH})_{2} \mathrm{D}_{3}\left(10^{-8} \mathrm{M}\right)$. Aprotinin or $\alpha_{2}$-antiplasmin were added at a concentration of $10^{-5} \mathrm{M}$ at the beginning of the culture. After 8 days the number of TRAP+ve MNCs were counted.

$\left(10^{-5} \mathrm{M}\right)$, or $\alpha_{2}$-antiplasmin to the cultures did not effect the number of TRAP+ve MNCs formed (Table 3).

\section{Osteoclast migration and fusion}

The effects of the proteinase inhibitors on the number of TRAP+ve cells in both the periosteum and mineralized matrix were determined at the beginning of the experiment and after 3 and 6 days of culture (Fig. 3). As the TRAP cells were often multinucleate, especially in the excavating marrow cavity, both TRAP cell profiles and nuclei were counted. The SP inhibitor, aprotinin, produced a significant reduction of approximately $55 \%$ in the invasion of the mineralized matrix by TRAP+ve cells after 3 days with a concomitant accumulation of TRAP+ve cells in the periosteum, thus showing that the SP inhibitors do not stop the formation of new TRAP+ve cells. A similar situation was found for the number of nuclei per TRAP+ve cell. However, after 6 days culture with aprotinin the numbers of TRAP+ve cells and nuclei per TRAP+ve cell were similar to the control cultures (Fig. 3). In contrast, the MMP inhibitor, CT1399, completely prevented the invasion of the mineralized matrix by TRAP+ve cells after 3 days, with a concomitant increase in the number of TRAP+ve cells in the periosteum. After 6 days, CT1399 still produced a significant reduction in the migration of TRAP+ve cells although its effects were incomplete (Fig. 3). None of the inhibitors appear to affect the intrinsic ability of cells to fuse.

\section{Degradation of bone-like matrix}

To determine whether the PA system is involved in the degradation of non-mineralized bone matrix, primary osteoblasts were cultured on ${ }^{3} \mathrm{H}$-labelled bone-like matrix produced by MC3T3-E1 cells. Mouse osteoblasts cultured for $72 \mathrm{~h}$ in the absence of serum produced neither basal nor $1,25-(\mathrm{OH})_{2} \mathrm{D}_{3}$-stimulated matrix breakdown, but the stimulated osteoblasts produced a threefold increase in 


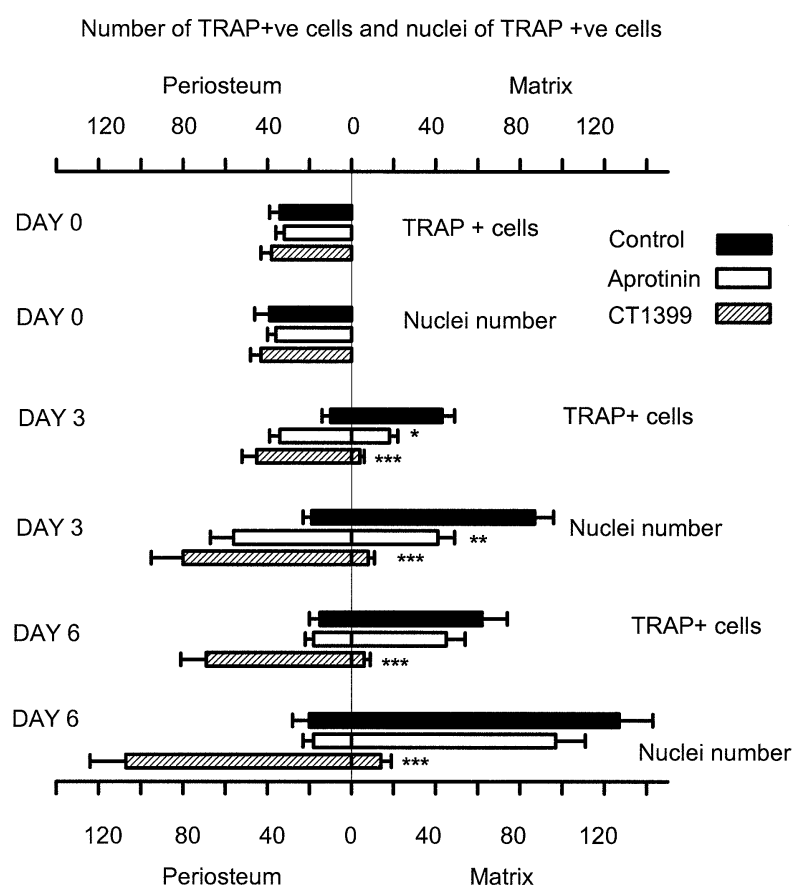

Figure 3 Effects of proteinase inhibitors on the migration of TRAP+ve cells to the calcified cartilage in metatarsal explants. Metatarsals were obtained from 3 litters of 17 -day-old fetal mice. The metatarsal triads of the left limb were cultured in control conditions with $1,25-(\mathrm{OH})_{2} \mathrm{D}_{3}$ and those of the corresponding right limbs were cultured in the presence of $1,25-(\mathrm{OH})_{2} \mathrm{D}_{3}$ and either CT1399 $\left(10^{-6} \mathrm{M}\right)$ or aprotinin $\left(10^{-6} \mathrm{M}\right)$ for the indicated times. The number of TRAP+ve cells and their nuclei localized inside and outside the calcified cartilage were counted. Counts inside the calcified cartilage are shown to the right of the ' 0 ' axis and those within the periosteum are shown to the left. Thus each bar (left and right) expresses the total numbers in one metatarsal. Counts at day 0,3 and 6 are the means \pm S.E.M. of, respectively, 18,15 , and 21 metatarsals. ${ }^{*} P<0 \cdot 05,{ }^{* *} P<0 \cdot 01,{ }^{* * *} P<0 \cdot 001$ compared with controls.

matrix degradation when plasminogen was added to the cultures (Fig. 4). Plasminogen-dependent matrix breakdown was significantly inhibited by the SP inhibitors, aprotinin $\left(10^{-5} \mathrm{M}\right)$ and $\alpha_{2}$-antiplasmin $\left(10^{-5} \mathrm{M}\right)$. Furthermore, plasminogen-dependent breakdown was inhibited by the MMP inhibitor, CT1399 $\left(10^{-6} \mathrm{M}\right)$.

\section{Degradation of type I collagen films}

To confirm a role for the PA system in the degradation of type I collagen, primary osteoblasts were cultured on ${ }^{14} \mathrm{C}$-labelled type I collagen films for $48 \mathrm{~h}$. Aprotinin dose-dependently inhibited $1,25-(\mathrm{OH})_{2} \mathrm{D}_{3}$-stimulated collagen breakdown by mouse osteoblasts (Fig. 5). CT1399 produced a complete inhibition whilst the SP inhibitors only produced about a $55 \%$ reduction in type I collagenolysis.

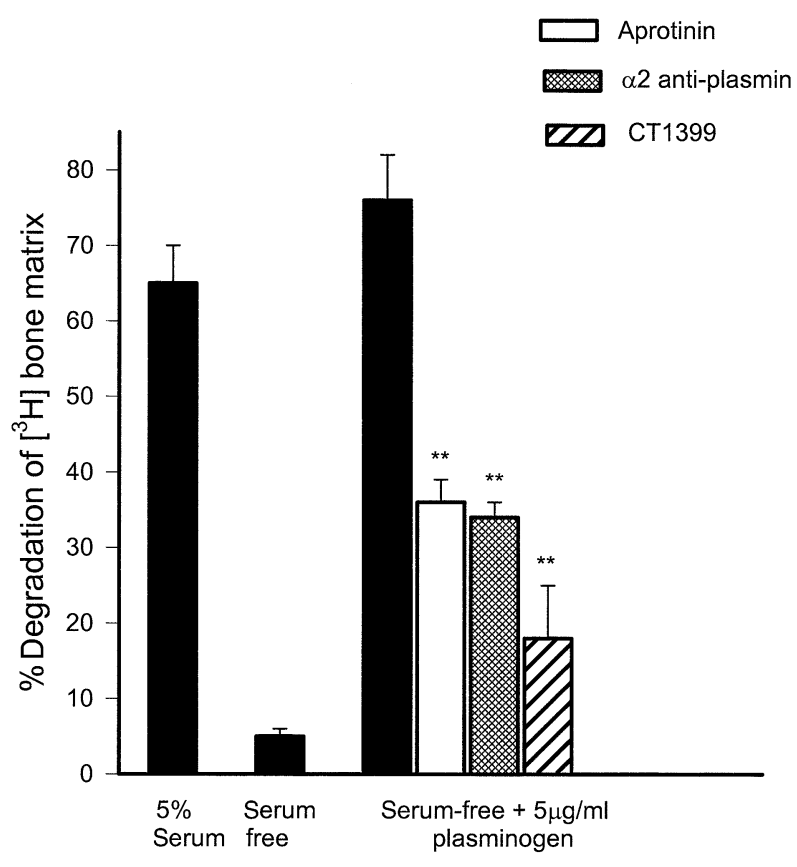

Figure 4 Effects of proteinase inhibitors on the degradation of non-mineralized bone matrix. Primary mouse osteoblasts were cultured for $72 \mathrm{~h}$ on ${ }^{3} \mathrm{H}$-labelled extracellular matrices and stimulated with $1,25-(\mathrm{OH})_{2} \mathrm{D}_{3}\left(10^{-8} \mathrm{M}\right)$ in the presence of $5 \%$ serum, in serum-free medium or in serum-free medium supplemented with $5 \mu \mathrm{g} / \mathrm{ml}$ plasminogen. Aprotinin $\left(10^{-5} \mathrm{M}\right)$, $\alpha_{2}$-antiplasmin $\left(10^{-5} \mathrm{M}\right)$ or CT1399 $\left(10^{-6} \mathrm{M}\right)$ were added to cultures containing $5 \mu \mathrm{g} / \mathrm{ml}$ plasminogen. The results are expressed as percentage degradation of ${ }^{3} \mathrm{H}$-labelled bone matrix. Each bar represents the mean \pm S.E.M. of 6 wells. Aprotinin, $\alpha_{2}$-antiplasmin and CT1399 inhibited degradation of ${ }^{3} \mathrm{H}$-labelled bone matrix. ${ }^{* *} P<0 \cdot 01$ compared with the control.

Expression of PAs and their inhibitors in osteoblasts

RT-PCR analysis was used to establish expression of mRNA for the plasminogen activators and their inhibitors in unstimulated primary mouse osteoblasts using specific oligonucleotide primers. As shown in Fig. 6, RT-PCR analysis showed that osteoblasts express mRNA transcripts for tPA, uPA and the type-I receptor for uPA (uPAR-I), PAI-1, PAI-2 and the broad spectrum inhibitor, PN-1. The authenticity of the sequences was verified by automated sequencing. The primers for PAI-2 generated PCR fragments between 194 and $420 \mathrm{bp}$. The band at 194 was verified as PAI-2.

\section{Expression of $P A$ s in osteoclasts}

Expression of mRNA for tPA and uPA was investigated by in situ hybridization studies on osteoclasts isolated from the long bones of 6-day-old mice. Figure 7A shows a typical multinucleate showing expression of tPA mRNA. For comparison, the sense probe for tPA was used as a negative control and showed negligible hybridization to 


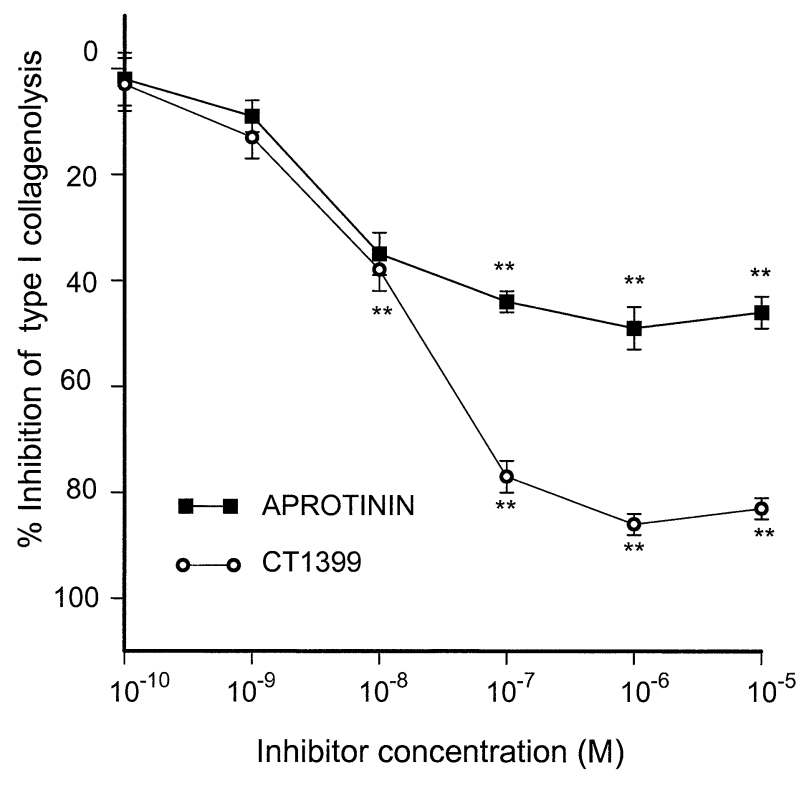

Figure 5 Effects of proteinase inhibitors on the degradation of ${ }^{14} \mathrm{C}$-labelled type I collagen films by mouse osteoblasts. Primary mouse osteoblasts were stimulated by $1,25-(\mathrm{OH})_{2} \mathrm{D}_{3}\left(10^{-8} \mathrm{M}\right)$ after $48 \mathrm{~h}$. The results are expressed as percentage inhibition of $1,25-(\mathrm{OH})_{2} \mathrm{D}_{3}$-stimulated ${ }^{14} \mathrm{C}$ release, which was arbitrarily set to $100 \%$. Each point is the mean \pm S.E.M. of six wells. The inhibitory effects of CT1399 $\left(10^{-8}-10^{-5} \mathrm{M}\right)$ and aprotinin $\left(10^{-8}-10^{-5} \mathrm{M}\right)$ were statistically significant, ${ }^{*} P<0.01$ compared with control. The percentage release of isotope by $1,25-(\mathrm{OH})_{2} \mathrm{D}_{3}$-stimulated mouse osteoblasts was $64 \cdot 7 \pm 5 \cdot 9$ which was obtained after subtracting the unstimulated release of isotope $(23 \cdot 7 \pm 3 \cdot 7)$

tPA mRNA (Fig. 7B). Osteoclasts cultured on type I collagen also exhibited expression of uPA as shown in Fig. 7C. Osteoclasts hybridized with the sense probe as a comparison exhibited only a weak signal compared with the antisense probe (Fig. 7D). Since MMP-9 is expressed at high levels in osteoclasts this was used as an additional positive control. As shown in Fig. 7E, osteoclasts exhibited a strong signal for the MMP-9 antisense riboprobe. The sense probe did not hybridize with MMP-9 mRNA (Fig. 7F).

\section{Discussion}

The data presented demonstrate that the PA/plasmin system plays a significant role in the bone resorption cascade. Using selective proteinase inhibitors we have shown that the PA/plasmin system is involved in both the migration of osteoclasts to future resorption sites and in osteoblast-mediated degradation of type I collagen. The $\mathrm{PA} /$ plasmin system, however, is not involved in either osteoclast formation or osteoclast resorptive activity. Furthermore, we have also demonstrated the expression of various components of the PA/plasmin system in primary mouse osteoblasts and osteoclasts.

Aprotinin is a small extremely stable peptide that reacts rapidly with plasmin to form high-affinity complexes (with a $K_{\mathrm{d}}$ of $10^{-9}-10^{-10} \mathrm{M}$ ). In contrast to $\alpha_{2^{-}}$ antiplasmin and $\alpha_{1}$-antitrypsin, the main inhibitor present in plasma, aprotinin also inhibits plasmin when it is bound to the plasminogen/plasmin surface receptors (Stephens et al. 1989, Bizik et al. 1990) found on many cell types (Mignatti et al. 1986). Our demonstration that two separate inhibitors of the $\mathrm{PA} /$ plasmin system partially inhibited bone resorption in neonatal calvarial explants that were cultured in serum devoid of neutral proteinase inhibitor activity is similar to the findings of Leloup et al. (1994) who found that aprotinin and $\alpha_{2}$-antiplasmin only inhibited bone resorption in fetal bone explants cultured under similar serum conditions. This suggests that proteinase inhibitors present in serum neutralize SP activity produced by osteoclasts and osteoblasts. Neonatal calvarial bone resorption reflects mainly post-mitotic events, namely the fusion of preosteoclasts, the migration of osteoclast to resorption sites, the activation of fully developed mature osteoclasts and osteoblast degradation of collagen fibrils whilst it is virtually independent of proliferation of

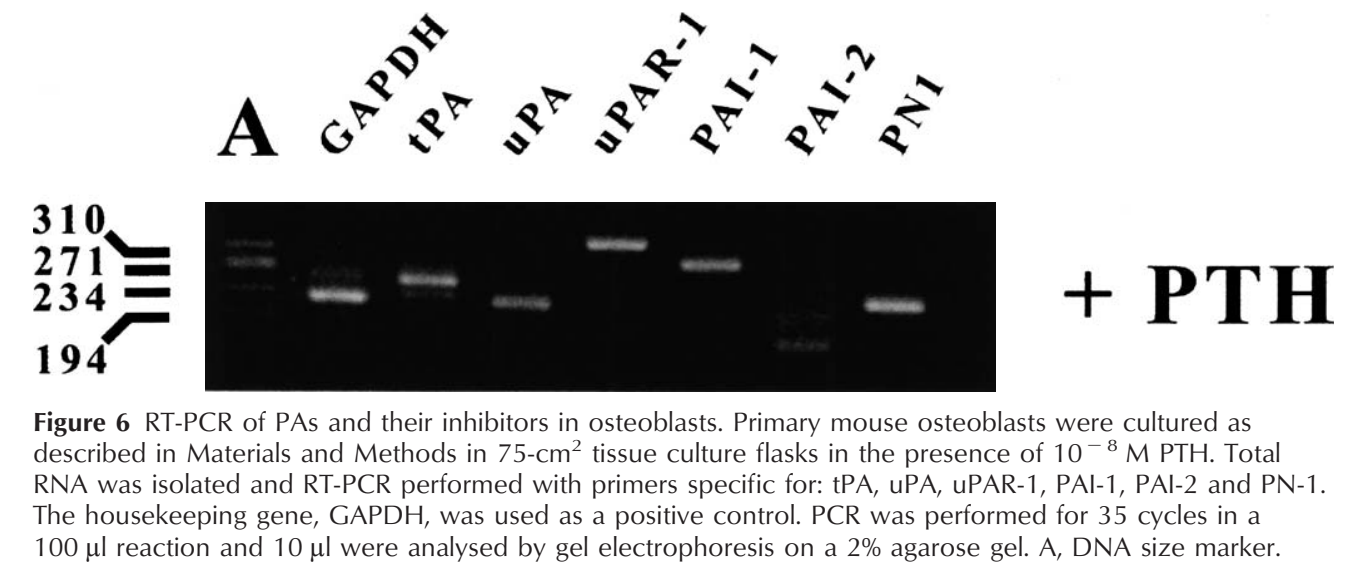



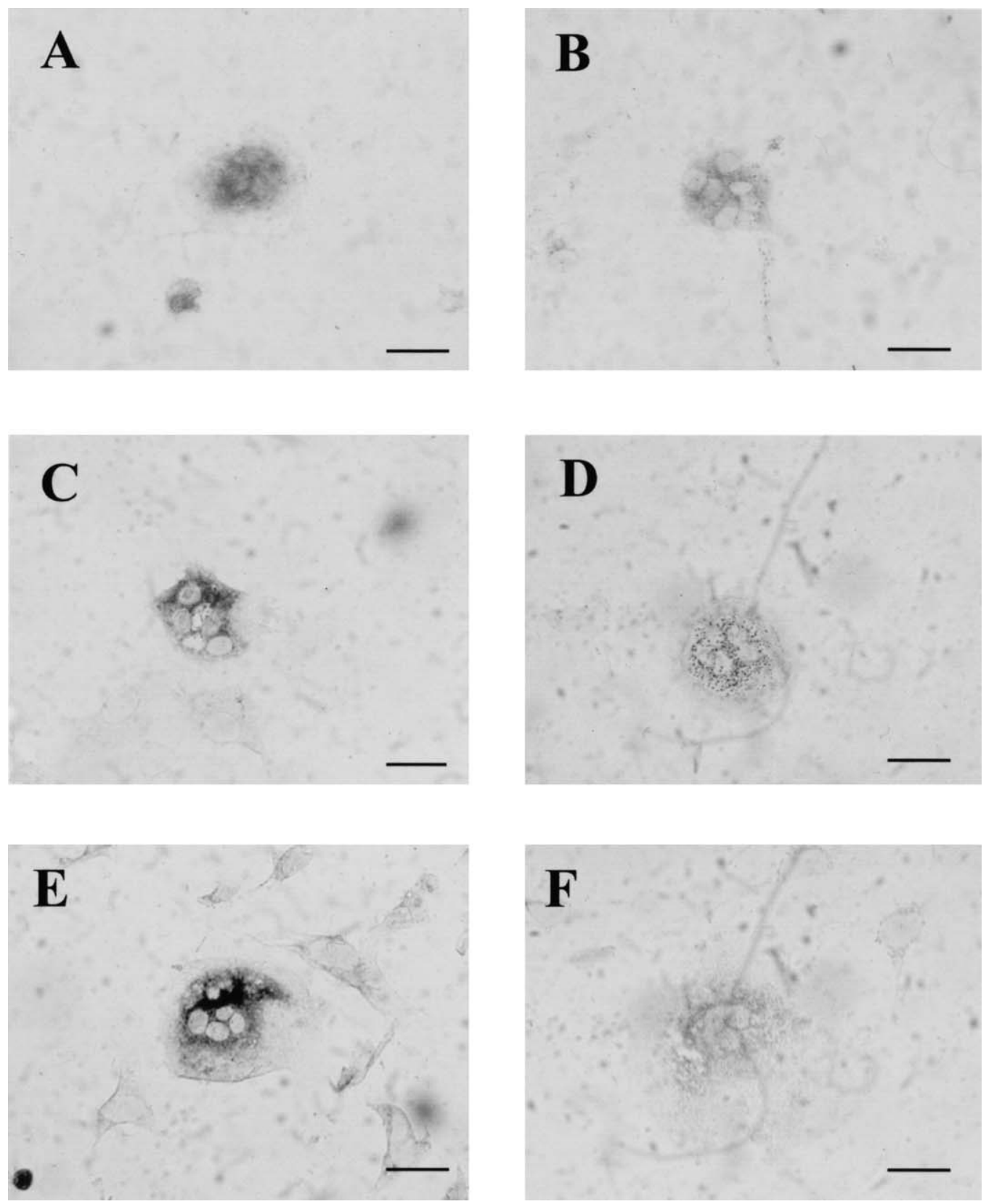

Figure 7 In situ hybridization of tPA and UPA in isolated osteoclasts. Osteoclasts were prepared as described in Materials and Methods and coated on rat tail type I collagen-coated coverslips. Coverslips were hybridized with (A) tPA antisense riboprobe, (B) tPA sense riboprobe, (C) UPA antisense riboprobe, (D) UPA sense riboprobe, (E) osteoclasts hybridized with MMP-9 antisense and (F) MMP-9 sense riboprobe. Bar $=50 \mu \mathrm{m}$. Osteoclasts exhibited expression of $\mathrm{UPA}$ and IPA when hybridized with the respective antisense riboprobes and were positive for MMP-9 mRNA expression.

osteoclast progenitors. This probably explains why the SP inhibitors, aprotinin and $\alpha_{2}$-antiplasmin, only produced a partial inhibition in calvarial bone resorption, since SP activity would appear to be limited to the osteoblastmediated degradation of the osteoid layer in this culture system and osteoclast migration.
It is widely believed that prior to osteoclastic resorption, the bone surface is freed of a thin investing layer of non-mineralized collagen fibrils. Although osteoblastderived MMPs, in particular collagenase, have been implicated in this process, it has been suggested that the $\mathrm{PA}$ /plasmin system may also be involved in this process 
(Thomson et al. 1989). Our findings that osteoblastmediated degradation of both type I collagen and bonelike matrix is dependent on the presence of plasminogen and that the SP inhibitor, aprotinin, partially prevented osteoblast-mediated degradation of these substrates supports the concept that the PA/plasmin system is involved in this aspect of the bone resorption process. Consistent with a role for the PA/plasmin system in osteoid degradation it has been shown that degradation of nonmineralized matrix by cocultures of osteoblasts and osteoclasts is decreased by combined inactivation of $\mathrm{uPA}$ and $\mathrm{tPA}$ genes (Daci et al. 1999). Furthermore, our demonstration that osteoblasts express tPA and uPA is in accordance with previous studies that have shown that a variety of bone resorbing agents upregulate PA activity in osteoblasts (Hamilton et al. 1984, 1985, Allan \& Martin 1995). Although we have not demonstrated the precise mechanism of action of the PA/plasmin system in collagen degradation it is known that plasmin will activate MMPs, particularly prostromelysin- 1 and -2 . In concert, plasmin and stromelysins can activate other osteoblast-derived MMPs (Meikle et al. 1992), in particular collagenase and gelatinase B (Murphy \& Knauper 1997), which may be directly responsible for the type I collagen degradation (Hill et al. 1995). RT-PCR analysis also revealed expression of the serine proteinase inhibitors, PAI-1 and PN-1, in primary mouse osteoblasts. Previous studies have demonstrated that PAI-1 mRNA is decreased in rat osteoblasts by PTH and increased by treatment with transforming growth factor- $\beta$ (TGF- $\beta$ ) (Allan et al. 1991, Fukumoto et al. 1992) thus highlighting the importance of PAI-1 in regulating the PA/plasmin system in rat osteoblasts. Allan and Martin (1995) demonstrated that expression of PAI-2 and PN-1 in rat calvarial osteoblasts was not modulated by prostaglandin $\mathrm{E}_{2}$ whereas PAI-1 was modulated in a biphasic manner.

Our finding that aprotinin prevented the migration of osteoclasts from the periosteum to the mineralized matrix in 17-day-old fetal metatarsals supports the findings of Hoekman et al. (1992), who demonstrated that tPA stimulated osteoclastic resorption in these explants, an event that is indicative of osteoclast migration to the calcified matrix. Leloup et al. (1994) also demonstrated that $\mathrm{uPA}$ is the main PA present in extracts of cultured fetal mouse metatarsals. Although Leloup et al. (1994) reported that inhibitors of plasmin did not influence metatarsal bone resorption, they found that when the explants were cultured in serum depleted of plasmin inhibitors there was enhanced bone resorption suggesting that the PA/plasmin system is involved. Furthermore, LeLoup et al. (1996) subsequently demonstrated that in mice with an inactivated uPA gene, bone resorption was reduced at the commencement of culture in the metatarsal explants whereas inactivation of the tPA gene had no effect on bone resorption in fetal metatarsal explants.
The inhibitory activity of aprotinin against the invasion of preosteoclasts and the degradation of type I collagen by osteoblasts is comparable with the inhibitory activity of aprotinin in several other culture models in which it contributed to establish the role of the PA/plasmin system in either the invasion or the degradation of extracellular matrices (Mignatti et al. 1986, Cajot et al. 1989, Quax et al. 1991).

The expression of tPA and uPA has been identified in osteoclasts both at the message level by RT-PCR (Yang et al. 1997), and at the protein level by immunocytochemistry (Grills et al. 1990). However, our demonstration that aprotinin had no inhibitory effect on osteoclast lacunar resorptive activity suggests that, at least under the in vitro conditions used in this study, the PA/plasmin system is not directly involved in this aspect of the resorption cascade. These findings are consistent with the results reported by Daci et al. (1999) in which osteoclasts derived from mice with a combined inactivation of both $\mathrm{uPA}$ and $\mathrm{PPA}$ were still able to resorb dentine. Nonetheless, there are several potential roles for the osteoclast-derived PAs in bone. These include the activation of latent proteases (Kwaan 1992), activation of latent growth factors (Martin et al. 1993, Lalou et al. 1994), and a nonproteolytic role as a mitogenic agent (Kirchheimer et al. 1987, Rabbani et al. 1990). The activation of various proenzymes by the PA system in osteoclasts, including enzymes that degrade extracellular matrix proteins such as prostromelysin and procollagenase, could aid in the resorption of bone (Delaisse \& Vaes 1992). Thus, since there are various proteolytic enzymes that appear to have overlapping functions in the activation of proenzymes or paracrine factors involved in bone resorption, the PA system may be one of several redundant mechanisms involved in this process. Another function of the PA system in osteoclasts may be to activate paracrine factors involved in the regulation of bone remodelling (Martin et al. 1993). Plasmin has been shown to dissociate insulin-like growth factor-I from its binding protein in human osteosarcoma cells and to activate the interleukin- $1 \beta$ precursor and latent TGF- $\beta$ (Kwaan 1992, Martin et al. 1993). In this study, the SP inhibitors had no effect on the formation of TRAP+ve MNCs. This is supported by Daci et al. (1999) who reported that cocultures of primary osteoblasts and bone marrow cells derived from mice with a combined inactivation of uPA and tPA genes were both capable of forming TRAP+ve MNCs.

In summary, we demonstrate that serine proteinases are involved in osteoblast-mediated degradation of type I collagen and osteoclast migration to future resorption sites. Osteoclasts and osteoblasts express both tPA and uPA mRNA. However, serine proteinases do not appear to play a role in osteoclast formation or osteoclast resorptive activity. It would seem that these serine proteinases may play an important role in the invasive and migratory 
acitivities of osteoclasts and in facilitating osteoclast access to mineralized bone matrix.

\section{References}

Allan EH \& Martin TJ 1995 Prostaglandin $\mathrm{E}_{2}$ regulates production of plasminogen activator isoenzymes, urokinase receptor, and plasminogen activator inhibitor-1 in primary cultures of rat calvarial osteoblasts. Journal of Cell Physiology 165 521-529.

Allan EH, Zeheb R, Gelehrter TD, Heaton JH, Fukumoto S, Yee JA \& Martin TJ 1991 Transforming growth factor beta inhibits plasminogen activator (PA) activity and stimulates production of urokinase-type PA, PA inhibitor-1 mRNA, and protein in rat osteoblast-like cells. Journal of Cell Physiology 149 34-43.

Baron R 1989 Molecular mechanisms of bone resorption by the osteoclast. Anatomical Record 224 317-324.

Bizik J, Lizonova A, Stephens RW, Grofova M \& Vaheri A 1990 Plasminogen activation by t-PA on the surface of human melanoma cells in the presence of alpha 2 macroglobulin. Cell Regulation 1 895-905.

Blair HC, Teitelbaum SL, Ghiselli R \& Gluck S 1989 Osteoclastic bone resorption by a polarized vacuolar proton pump. Science $\mathbf{2 4 5}$ 855-857.

Blavier L \& Delaisse JM 1995 Matrix metalloproteinases are obligatory for migration of preosteoclasts to the developing marrow cavity of primitive long bones. Journal of Cell Science 108 3649-3659.

Boyde A, Ali NN \& Jones SJ 1984 Resorption of dentine by isolated osteoclasts in vitro. British Dental Journal 156 216-220.

Cajot JF, Schleuning WD, Medcalf RL, Bamat J, Testuz J, Liebermann L \& Sordat B 1989 Mouse L cells expressing human prourokinase-type plasminogen activator: Effects on extracellular matrix degradation and invasion. Journal of Cell Biology 109 915-925.

Daci E, Udagawa N, Martin TJ, Bouillon R \& Carmeliet G 1999 The role of the plasminogen system in bone resorption in vitro. Journal of Bone Mineral Research 14 946-952.

Delaisse JM \& Vaes G 1992 Mechanisms of mineral solubilization and matrix degradation in osteoclastic bone resorption. In Biology and Physiology of the Osteoclast, pp 289-314. Eds BR Rifkin \& CV Gay. Boca Raton: CRC Press.

Fukumoto S, Allan EH, Yee JA, Gelehrter TD \& Martin TJ 1992 Plasminogen activator regulation in osteoblasts: parathyroid hormone inhibition of type-1 plasminogen activator inhibitor and its mRNA. Journal of Cell Physiology 152 346-355.

Gavrilovic J, Reynolds JJ \& Murphy G 1985 Inhibition of type I collagen film degradation by tumour cells using a specific antibody to collagenase and the specific inhibitor of metalloproteinases (TIMP). Cell Biology International Reports 9 1097-1107.

Grills BL, Gallagher JA, Allan EH, Yumita S \& Martin TJ 1990 Identification of plasminogen activator in osteoclasts. Journal of Bone Mineral Research 5 499-505.

Hamilton JA, Lingelbach SR, Partridge NC \& Martin TJ 1984 Stimulation of plasminogen activator in osteoblast-like cells by bone-resorbing agents. Biochemical and Biophysical Research Communications 122 230-235.

Hamilton JA, Lingelbach S, Partridge NC \& Martin TJ 1985 Regulation of plasminogen activator production by bone-resorbing hormones in normal and malignant osteoblasts. Endocrinology 116 2186-2191.

Heath JK, Atkinson SJ, Meikle MC \& Reynolds JJ 1984 Mouse osteoblasts synthesize collagenase in response to bone resorbing agents. Biochimica et Biophysica Acta 802 151-154.

Hill PA, Docherty AJP, Bottomley KMK, O'Connell JP, Morphy JR, Reynolds JJ \& Meikle MC 1995 Inhibition of bone resorption in vitro by selective inhibitors of gelatinase and collagenase. Biochemical Journal 308 167-175.
Hoekman K, Lowik CWGM, van de Ruit M, Bijvoet OLM, Verheijen JH \& Papapoulos SE 1992 The effect of tissue type plasminogen activator on osteoclastic resorption in embryonic mouse long bone explants: a possible role for the growth factor domain of tPA. Bone and Mineral 17 1-14.

Kirchheimer JC, Wojta J, Christ G \& Binder BR 1987 Proliferation of a human epidermal tumor cell line stimulated by urokinase FASEB Journal 1 125-128.

Knudsen BS, Silverstein RL, Leung LL, Harpel PC \& Nachman RL 1986 Binding of plasminogen to extracellular matrix. Journal of Biological Chemistry 261 10765-10771.

Kwaan HC 1992 The plasminogen-plasmin system in malignancy. Cancer Metastasis Review 11 291-311.

Lalou C, Silve C, Rosato R, Segovia B \& Bonoux M 1994 Interactions between insulin-like growth factor-I and the system of plasminogen activators and their inhibitors in the control of IGF-binding protein 3 production and proteolysis in human osteosarcoma cells. Endocrinology 135 2318-2326.

Leloup G, Delaisse JM \& Vaes G 1994 Relationship of the plasminogen activator/plasmin cascade to osteoclast invasion and mineral resorption in explanted fetal metatarsal bones. Journal of Bone Mineral Research 9 891-902.

Leloup G, Lemoine P, Carmeliet P \& Vaes G 1996 Bone resorption and response to calcium-regulating hormones in the absence of tissue or urokinase plasminogen activator or of their type 1 inhibitor. Journal of Bone Mineral Research 11 1146-1157.

Martin TJ, Allan EH \& Fukumoto S 1993 The plasminogen activator and inhibitor system in bone remodelling. Growth Regulation 3 209-214.

Meikle MC, Bord S, Hembry RM, Compston J, Croucher PI \& Reynolds JJ 1992 Human osteoblasts in culture synthesize collagenase and other matrix metalloproteinases in response to osteotropic hormones and cytokines Journal of Cell Science $\mathbf{1 0 3}$ 433-440.

Mignatti P \& Rifkin DB 1993 Biology and biochemistry of proteinases in tumor invasion. Physiological Reviews 73 161-195.

Mignatti P, Robbins E \& Rifkin DB 1986 Tumour invasion through the human amniotic membrane: requirement for a proteinase cascade. Cell 47 487-498.

Murphy G \& Knauper V 1997 Relating matrix metalloproteinase structure to function: why the hemopexin domain? Matrix Biology 15 511-518.

Murphy G, Ward R, Gavrilovic J \& Atkinson S 1992 Physiological mechanisms for metalloproteinase activation. Matrix Supplement 1 224-230.

Quarles LD, Yohay DA, Lever LW, Caton R \& Wenstrup RJ 1992 Distinct proliferative and differentiated stages of murine MC3T3-E1 cells in culture: an in vitro model of osteoblast development. Journal of Bone Mineral Research 7 683-692.

Quax PHA, Pedersen N, Masucci MT, Weening-Verhoeff EJD, Dano K, Verheijen JH \& Blasi F 1991 Complementation between urokinase-producing and receptor-producing cells in extracellular matrix degradation. Cell Regulation 2 793-803.

Rabbani SA, Desjardins J, Bell AW, Banville D, Mazar A, Henkin J \& Goltzman D 1990 An amino-terminal fragment of urokinase isolated from a prostate cancer cell line (PC-3) is mitogenic for osteoblast-like cells. Biochemical and Biophysical Research Communications 173 1058-1064.

Reynolds JJ \& Dingle JT 1970 A sensitive in vitro method for studying the induction and inhibition of bone resorption. Calcified Tissue Research 4 339-349.

Ronday HK, Smits HH, Quax PH, van der Pluijm G, Lowik CW, Breedveld FC \& Verheijen JH 1997 Bone matrix degradation by the plasminogen activation system. Possible mechanism of bone destruction in arthritis. British Journal of Rheumatology 36 9-15.

Stephens RW, Pollanen J, Tapiovaara H, Leung KC, Sim PS, Salonen EM, Ronne E, Behrendt N, Dano K \& Vaheri A 1989 Activation 
of pro-urokinase and plasminogen on human sarcoma cells: a proteolytic system with surface bound reactants Journal of Cell Biology 108 1987-1995.

Suda T, Takahashi N \& Martin TJ 1992 Modulation of osteoclast differentiation. Endocrine Reviews 13 66-88.

Takahashi N, Akatsu T, Sasati T, Nicholson GC, Moseby JM, Martin TJ \& Suda T. 1988 Induction of calcitonin receptors by 1,25 dihydroxyvitamin $\mathrm{D}_{2}$ in osteoclast-like multinucleated cells formed from mouse bone marrow cells. Endocrinology 123 1504-1510.

Thomson BM, Atkinson SJ, McGarrity AM, Hembry RM, Reynolds JJ \& Meikle MC 1989 Type I collagen degradation by mouse calvarial osteoblasts stimulated with 1,25-dihydroxyvitamin D-3: evidence for a plasminogen-plasmin-metalloproteinase activation cascade. Biochimica et Biophysica Acta 1014 125-132.

Vassalli J-D, Sappino AP \& Belin D 1991 The Plasminogen Activator/Plasminogen System. Journal of Clinical Investigation $\mathbf{8 8}$ 1067-1072.

Yang JN, Allan EH, Anderson GI, Martin TJ \& Minkin C 1997 Plasminogen activator system in osteoclasts. Journal of Bone Mineral Research 12 761-768.

Received 14 May 2003

Accepted 2 June 2003 